\title{
INTERNATIONAL REAL BUSINESS CYCLES
}

\author{
by
}

Mario J. Crucini

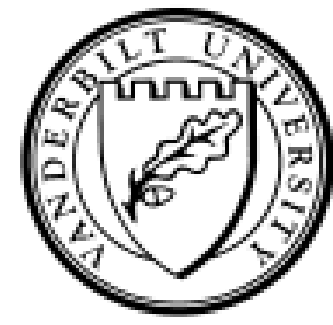

Working Paper No. 06-W17

July 2006

\section{DEPARTMENT OF ECONOMICS \\ VANDERBILT UNIVERSITY}

NASHVILLE, TN 37235

www.vanderbilt.edu/econ 


\title{
INTERNATIONAL REAL BUSINESS CYCLES
}

\author{
Mario J. Crucini*
}

July 2006

\begin{abstract}
This paper is a non-technical review of research developments in the international real business cycle literature. International business cycle facts are summarize with particular attention to the sources of output variance from the expenditure side of the NIPA and the production side, using a familiar neoclassical production function. Theoretical developments focus on the how consumption smoothing and investment dynamics shape the current account; the search for sources and propagation mechanisms of international business cycle comovement and key facets of relative price determination (the real exchange rate and the terms of trade).
\end{abstract}

\section{International real business cycles}

Business cycles are the recurrent fluctuations of national output relative to its long-term growth trend. The qualitative features of these fluctuations are common to virtually all economies, with their quantitative properties differing somewhat across countries and time periods. Modern research seeks to summarize the statistical properties of business cycles and formally model them as the outcome of purposeful decisions by individuals and firms who react to changes in their economic environment and an uncertain future. Whereas closed economy analysis focuses on responses to domestic shocks and policy actions, open economy analysis adds to this, international policy interaction and spillovers of foreign shocks to

\footnotetext{
*Department of Economics, Vanderbilt University. This paper was written for the The New Palgrave: A Dictionary of Economics, 2nd Edition, edited by Lawrence Blume and Steven Durlauf. The author is grateful to Ben Eden for helpful comments.
} 
the domestic economy. The term 'real' indicates a sub-area of the business cycle research program that focuses on non-monetary dimensions such as changes in productivity, taxes and government spending, rather than changes in the money supply and monetary policy.

\section{Measuring international business cycles}

What may be surprising to the uninitiated is the controversy surrounding business cycle measurement itself. Measures most often cited in the press are the calendar dates of business cycle peaks and troughs. In the United States, these dates are identified by the Business Cycle Dating Committee at National Bureau of Economic Research. A committee affiliated with the Center for Economic Policy Studies serves the same function for Europe. The logic of the methods used by both committees dates back to the classic contribution of Burns and Mitchell (1946), pioneers of formal business cycle measurement.

In academic work, economists favor econometric methods in which the logarithm of real gross domestic product, $y_{t}$, is decomposed into a growth trend, $y_{g, t}$, and a business cycle component, $y_{c, t}$ :

$$
y_{t}=y_{g, t}+y_{c, t}
$$

We employ the Hodrick-Prescott (1997) to achieve this decomposition since it is widely used in the literature. ${ }^{1}$ The Hodrick-Prescott filter provides a smooth estimate of the growth trend, $y_{g, t}$, and the cycle is computed as the difference between the growth trend and the original series.

Figure 1 displays the business cycle component of the logarithm of Gross Domestic Product for eight industrialized countries: Australia, Canada, France, Germany, Italy, Japan, the United Kingdom, and the United States. As is evident, business expansions and contractions are persistent. One also sees common features such as the simultaneous emergence of a recession in the 1980's in most countries.

We organize our discussion of business cycle facts around two equations. The

\footnotetext{
${ }^{1} \mathrm{~A}$ large applied econometrics literature acheives trend and cycle decompositions by applying identifying assumptions on the innovations to the trend and cycle components of aggregate output. See for example, Beveridge and Nelson (1981), Cochrane (1994), Crucini and Shintani (2006) and Stock and Watson (2005).
} 
first is the national income and product accounts (NIPA) accounting identity: ${ }^{2}$

$$
Y_{t}=C_{t}+I_{t}+G_{t}+\left(X_{t}-M_{t}\right) .
$$

In words: the amount of output produced in the home country equals the sum of its uses in domestic private consumption and investment, $C_{t}$ and $I_{t}$, government spending, $G_{t}$, and exports, $X_{t}$. Imports are deducted to avoid double counting since they are already counted in the other expenditure components.

The variables have been ordered in terms of the fraction of output accounted for by each component. Averaging across time periods and countries, consumption accounts for about $58 \%$ of output, investment accounts for $23 \%$, while the percentages for government consumption, exports and imports are almost identical, at $18 \%, 19 \%$, and $19 \%$, respectively. With the exception of exports and imports, the ratios differ modestly across industrialized countries when long time averages are taken. We use equation (2.2) below to perform an expenditure-side decomposition of output variability.

The second relationship is a theoretical construct. The prototype model assumes that output is produced with two inputs, capital and labor. The production function relating inputs to outputs usually takes the form:

$$
Y_{t}=A_{t} K_{t}^{\alpha} N_{t}^{1-\alpha}
$$

where $A_{t}$ is total factor productivity, $K_{t}$ is the stock of physical capital in place at time $t, N_{t}$ is total hours of input at time $t$. The exponent $1-\alpha$ measures the share of national income paid to labor (e.g. salaries and wages) since labor is paid it's value marginal product in the model.

Taking logarithms of equation (2.3) provides the basis for the second variance decomposition:

$$
y_{t}=a_{t}+\alpha k_{t}+(1-\alpha) n_{t} .
$$

We compute $a_{t}$ as a residual, setting $\alpha=1 / 3$ (the share of labor income in national income) and using standard measures of physical capital and aggregate hours, as the inputs on the right-hand-side of the equation. We call this our production-side decomposition.

Table 1 contains business cycle statistics for each country using data from the first quarter of 1970 to the first quarter of 2005. Beginning with the variance of

\footnotetext{
${ }^{2}$ The OECD data satisify this identity when changes in inventories and a statistical discrepancy are included. We subtracted these two items from output when we perform the variance decomposition of output from the expenditure side.
} 
the cycle itself, we see that the U.S. has the most variable business cycle, with a standard deviation of $1.58 \%$ per quarter while France, at the other end of the scale, has a standard deviation of only $0.91 \%$. Australia, Canada, Germany, Italy, Japan and the U.K. have remarkably similar volatility, in the range of $1.32 \%$ to $1.48 \%$.

Turning to the details, we see that investment and trade flows are much more variable than output; consumption is less variable than output while government spending and the net-export-to-income ratio are the least variable. There are some quantitative differences across countries, but the rankings are robust.

The correlation of variables with output indicates the cyclicality of a variable. If the correlation is positive, the variable is said to be procyclical: on average, it rises when the economy is in an expansionary phase and falls when the economy is in a contractionary phase. All variables except government spending and the net export ratio are strongly procyclical, consumption and investment particularly so. In a statistical sense, government spending seems to provide some stabilization by virtue of its low variability and near zero correlation with the cycle. Imports are consistently more highly correlated with domestic output than are exports. This makes economic sense since import demand is influenced by domestic income while export demand depends on potentially diverse income developments across a country's trading partners.

On the production side of the equation, capital is less cyclically variable than either productivity or labor input (a notable exception is Japan). The ranking of the variability of labor input relative to productivity is ambiguous.

\subsection{Variance decompositions}

The variance decomposition of output from the expenditure-side or productionside is computed as:

$$
\operatorname{std}(y)=\sum_{z} s_{z} \cdot \operatorname{std}(z) \cdot \operatorname{corr}(z, y)
$$

where $s_{z}$ is either the expenditure share the production share for variable $z$ (productivity gets a weight of one), $\operatorname{std}(z)$ is the standard deviation of component $z$ over the cycle and $\operatorname{corr}(z, y)$ is the correlation between component $z$ and income. ${ }^{3}$

\footnotetext{
${ }^{3}$ The variance decomposition is exact in levels, but approximate in logs, because the NIPA identity involves levels. The variance decomposition is exact on the production side because of the log-linearity of the production function.
} 
On the expenditure side consumption and investment account for about $95 \%$ of the cyclical variation in aggregate demand. There is no consistent ordering of their relative importance. The reason for consumption's impact is that about twothirds of aggregate demand is accounted for by this component. While investment is a paltry $23 \%$ of aggregate demand, it is about twice as variable as consumption and therefore exerts an influence on the cycle larger than its expenditure share would suggest. Imports are often as important as consumption or investment while the contribution of exports is not robust across countries. However, since imports and exports enter the national income and product identity with opposite signs, they tend to cancel out. Fluctuations in government spending contribute little to the cycle for three reasons. First, government spending accounts for a relatively small amount of aggregate demand, close to the investment and trade shares and much lower than that of private consumption. Second, government spending is typically less variable than output. And third, the correlation between government spending and output is close to zero, on average. ${ }^{4}$

Turning to the production-side, total factor productivity and changes in labor input account for virtually all of the cyclical variation in output (the cross-country average contribution of these two combined is 95\%). This is because each of these variables is highly variable and highly correlated with output, much more so than is true of the physical capital stock. Moreover, capital's share in income is exactly one-half that of labor's, reducing it's influence relative to labor. While productivity and labor have a comparable influence, the source of the influence differs. Labor input is more variable than productivity, however, it gets a weight of two-thirds, less than the unit coefficient on total factor productivity (see equation $(2.4))$.

It should be stressed that while these accounting-based decompositions are useful in framing the discussion, they do not tell us what the underlying sources of business cycles are. To see this consider the distinction between choice variables and exogenous variables. In the prototype real business cycle model, productivity is the only exogenous source of economic change, all other variables are responding optimally to this variable. The model, then, tells us that productivity variation accounts for all of business cycle variation and the various facets of how this plays out across macroeconomic aggregates reflect the choices made by individuals, firms and governments, in response to these productivity changes.

Thus, in practice, there is a subtle link between exogenous impulses and en-

\footnotetext{
${ }^{4}$ In periods of war, such as World War II the picture is very different since government spending is a much larger fraction of output and is strongly pro-cyclical.
} 
dogenous responses to them. For example, Imbs (1994) introduces variable capital utilization into the model described above. Since capital utilization is not part of what we are measuring in our physical capital stock series we incorrectly allocate variation in capital utilization to productivity. It is natural to think that this leads us to over-estimate the role of productivity. Baxter and Farr (2005) show, however, that when one moves from a model with constant utilization of capital to one with variable utilization, the response of the economy to a productivity change of a fixed size is larger when utilization is variable compared to when it is fixed. This moves the bias in the other direction. The lesson here is that theory and measurement work best in concert to achieve the most accurate possible attribution of economic variance.

\subsection{International dimensions of the business cycle}

We turn, now, to key international facets of business cycles: i) the current account balance, ii) international business cycle comovement and iii) relative price determination.

\subsubsection{The current account}

An important goal of international business cycle research is to improve our understanding the time path of the current account balance or the trade balance. International trade focuses on the direction and composition of trade and often assumes balanced trade. International finance focuses on the current account, modeling the dynamics of savings and investment over time. Since the business cycle involves time variation, it is natural to emphasize the international finance perspective.

The current account equals the difference between savings and investment. National savings is the sum of private savings and public savings. Private savings is the difference between disposable income and private consumption while public savings is the difference between tax revenue and government expenditure.

$$
\begin{aligned}
C A_{t} & =S_{t}-I_{t} \\
S_{t} & =\underbrace{\left(Y_{t}-T_{t}-C_{t}\right)}_{\text {private saving }}+\underbrace{\left(T_{t}-G_{t}\right)}_{\text {public saving }}
\end{aligned}
$$

In a closed economy, of course, the current account is identically equal to zero each dollar of savings must be allocated to domestic investment. An open econ-

omy, freed from this constraint, rarely finds itself with a current account balance; 
when current savings fall short of (or exceeds) current investment levels a current account deficit (or surplus) obtains. Feldstein and Horioka (1980) vividly demonstrated that when the data are averaged over long periods of time, savings and investment rates are highly positively correlated - countries with higher than average savings rates tend to have higher than average investment rates. Business cycle correlations of saving and investment tend to be lower than the Feldstein-Horioka values, suggesting that large deviations in the current account are transitory. The correlation of national saving and national investment over the cycle ranges from a high of 0.80 in Italy to a low of 0.44 in both Australia and Germany (see Table 1).

\subsubsection{International business cycle comovement}

International comovement may be expressed in different ways; here we use the correlation of a foreign variable with it's U.S. counterpart. ${ }^{5}$ As is evident in Table 2 , positive movements of foreign variables with their U.S. counterparts are the rule, rather than the exception. In terms of rankings, output tends to be more correlated than the components of aggregate demand; investment and government spending have particularly low international correlations. ${ }^{6}$

Turning to the production-side, we see that U.S. labor input has the highest correlation with its counterpart abroad, ranging from 0.60 with the U.K. to a low of -0.17 with Italy. International productivity levels also tend to be positively correlated, though not to the extent of labor input. Changes in capital formation have a low international correlation, consistent with other facets of this input documented above. The highest international business cycle correlations are between Canada and the U.S., geographic neighbors with similar institutions and extensive trade relations.

\footnotetext{
${ }^{5}$ Kose, Otrok and Whiteman (2003), amoung others use state-space models in which there are world, country and idiosyncratic factors in the income process as well as in each component of aggregate demand. This method avoids an arbitrary choice of numeraire and helps to identify what economists refer to as the 'world business cycle.'

${ }^{6}$ The rankings are more ambiguous in a statistical sense and for a broader range of countries than Table 2 suggests (see Ambler, Cardia and Zimmerman (2004)).
} 


\subsubsection{Real exchange rates and the terms of trade}

The two key international relative prices are the real exchange rate and the terms of trade. The real exchange rate is:

$$
Q_{t}^{R}=\ln \left(E_{t} P_{t}^{*} / P_{t}\right)
$$

where $E_{t}$ is the nominal exchange rate between the home and foreign country and $P_{t}$ and $P_{t}^{*}$ are home and foreign price indices (usually the consumer price index), respectively. In words: $Q_{t}^{R}$ is the relative cost of the foreign consumption basket relative to the domestic consumption basket after converting to a common currency. According to the Purchasing Power Parity proposition, the dollar goes just as far in foreign countries as it does in the U.S. in terms of purchasing power. This implies that $Q_{t}^{R}=1$ at each point in time.

In practice, however, the real exchange rate is highly variable and very persistent. High variability suggests large absolute departures from parity, while high persistence implies that when a price gap opens up internationally, it tends to remain open for many months, rather than days or weeks. In terms of the time series measurement of this property, at business cycle frequencies, it appears that the real and nominal exchange rates have approximately the same variance while the price ratio term $\left(P_{t}^{*} / P_{t}\right)$ is very stable. For example, the standard deviation of the nominal exchange rate between the United States and France is about 8.52, close to the standard deviation of their bilateral real exchange rate at 7.95, while the price ratio has a standard deviation of only 1.17 (see Table 3 ). These numbers are typical of U.S. bilateral real exchange rates with respect to other industrialized countries. One also finds that the real exchange rate is not highly correlated with quantity variables such as output or even net exports (not shown).

Turning to the terms of trade, it is defined as:

$$
Q_{t}^{T}=P_{t}^{m} / P_{t}^{x}
$$

where $P_{t}^{m}$ and $P_{t}^{x}$ are import and export price indices for a particular country. Since these price indices are domestic deflators they are already expressed in the home currency terms and the spot exchange rate is not needed to convert them to common units. Unlike the real exchange rate, economic theory does not place

strong restrictions on the time series or cross-country behavior of the terms of trade. Given the presumption that countries import different goods than they export, we expect the terms of trade to be different from unity and it should fluctuate too. 
Australia and Japan have the highest terms of trade variability, about twice that of the other countries, with the exception of France, which experiences terms of trade variability between these extremes. The terms of trade does not have a robust correlation with either output or net exports.

\section{Modeling international business cycles}

Quantitative theoretical investigations of business cycles seek to account for business cycle facts using models in which consumers are thoughtful and informed, firms employ workers and utilize capital efficiently and policymakers use a combination of rules and discretion to achieve various economic objectives. The key dimensions of study are those unique to international economics: matching the international character of the world business cycle and the business cycle properties of the current account, the real exchange rate and the terms of trade.

\subsection{The current account}

The most rudimentary model of current account behavior is one in which a small open economy faces an exogenous world interest rate and income stream. To fix ideas, think of a small country that produces mostly oil with perfect access to international capital markets. If the country is always producing at capacity, all of its income variation is due to changes in the price of oil in world markets. What does the intertemporal approach to the current account predict in this circumstance?

The theory reduces the NIPA identity to: $S_{t}=Y_{t}-C_{t}$, so that consumption decisions effectively determine saving decisions. Investment is absent since we are abstracting from changes in production capacity and its utilization. While this model seems simplistic, the identity is deceptive since it suggests that only current income enters into the current consumption-savings decision. In fact, the most widely used setup has its roots in the seminal contribution of Friedman (1957), with individuals assumed to be able to draw upon the entire present discounted value of their future labor income. Whereas current income is the traditional argument in the Keynesian consumption function, wealth plays this role in modern macroeconomics. Since wealth is the sum of the market value of financial assets and all future anticipated flows of income, expectations play a central role in the modern consumption function. ${ }^{7}$

\footnotetext{
${ }^{7}$ There are many extensions to this basic framework that prevent individuals from drawing
} 
Much of the intuition for the impact of a changing income profile on the current account of a small open economy is available from Quah's (1990) formulation of the permanent income hypothesis. He assumes a constant interest rate, quadratic preferences and rational expectations. He allows income to contain both permanent and transitory shocks. If we assume income follows a first-order autoregressive process: $Y_{t+1}=\rho Y_{t}+\nu_{t+1}$, where $\nu_{t}$ is news about income (i.e. under Rational Expectations, news about income is: $\left.E_{t+1} Y_{t+1}-E_{t} Y_{t+1}=\nu_{t+1}\right)$, the predicted change in consumption in response to this news is:

$$
\Delta C_{t+1}=\frac{r}{1+r-\rho} \nu_{t+1}
$$

and the change in the current account on impact, assuming it was in balance initially, is:

$$
\begin{aligned}
\Delta C A_{t+1} & =\Delta Y_{t+1}-\Delta C_{t} \\
& =\nu_{t+1}-\frac{r}{1+r-\rho} \nu_{t+1} .
\end{aligned}
$$

Since output deviations from trend (the business cycle) are persistent it is safe to assume, $\rho>0$. A plausible value for $r$ is 0.05 (a $5 \%$ real interest rate). Note that the consumption response depends positively on persistence since wealth effects are rising in the persistence of the income change. As persistence moves from zero toward unity, the impact effect on the current account rises from close to unity toward zero. This algebra delivers a key prediction of the intertemporal approach, that consumption smoothing leads to current account surpluses during booms unless the income change is viewed as permanent (i.e., $\rho=1$ ) in which case the current account is predicted to be unchanged.

While there is evidence to suggest an interest rate channel on consumption, it does not help to resolve the counterfactual prediction of a procyclical current account from the consumption side, just established. There are two reasons for this. First, if interest rates are higher during a boom in the home country, individuals would tend to tilt consumption from current to future periods, the intertemporal substitution effect (i.e, postpone durable goods purchases). This would reinforce rather than overturn our prediction that the current account moves into surplus during a boom. If real interest rates actually fell during a boom, the intertemporal

upon their lifetime wealth for present consumption: collateral requirements, limits on debt-toincome ratios and credit histories. Discussion of these extensions is beyond the scope of this survey. 
substitution effect would operate in the right direction, but the evidence on the cyclicality of the real interest is ambiguous. Second, when we move to a general equilibrium setting, incorporating home and foreign responses, the increase in the real interest rate is shared by the two countries and therefore incapable of delivering the asymmetric consumption responses necessary to move the current account balance. This leaves us with the need to look elsewhere for a channel that moves the current account in a countercylical direction.

Returning to the algebra of the current account identity it would appear that what is needed for a countercyclical current account is for domestic investment to rise more than domestic savings during a business cycle expansion:

$$
\Delta C A_{t}=\Delta S_{t}-\Delta I_{t}=\left(\Delta Y_{t}-\Delta C_{t}\right)-\Delta I_{t}
$$

The identity reveals the tension between the consumption smoothing channel, whereby a transitory change in income is mostly saved, pushing the current account toward surplus and the investment channel, which pulls in the opposite direction, toward a deficit.

In a model with only one good, the consumption smoothing channel wins the contest unless the shocks are highly persistent (see, for example, Backus, Kehoe and Kydland (1992), Baxter and Crucini (1993) and Mendoza (1991)). Persistence, by increasing the impact response of consumption due to the larger wealth effect, helps to push the current account toward balance, leaving the investment channel to produce a deficit. Extensive empirical investigations of the intertemporal approach to the current account may be found in Glick and Rogoff (1995) and Nason and Rogers (2006). ${ }^{8}$

Extensions of the model to multiple goods helps avoid this unpleasant arithmetic because individuals want to increase consumption of both the domestic good and the foreign good, increasing import demand and reinforcing the tendency toward a deficit from a traditional trade channel. Demonstrations of this effect under complete and incomplete risksharing are found in Backus, Kehoe and Kydland (1994) and Arvanitis and Mikkola (1995), respectively. ${ }^{9}$

To summarize, early developments of the intertemporal approach to the current account emphasized the consumption smoothing channel and predicted that current account surpluses would occur when output was temporarily above trend. Current account surpluses are often described as good based on the idea that

\footnotetext{
${ }^{8}$ See Sachs (1981) for early evidence on the investment channel.

${ }^{9}$ See JoAnne Feeney (1994) for an insightful exposition of this issue.
} 
surpluses flow from good economic times. The complete model of the current account adds investment dynamics and allows for the possibility that investment-led booms produce current account deficits. These theoretical developments and their empirical implications have led to a more balanced view of the current account: that we need to understand the sources of the changes in the current account before making value judgements about them. ${ }^{10}$

\subsection{The world business cycle}

Conceptually, the world business cycle is simple to define: the deviation of world output from its growth trend. The practical difficulty is the measurement of world output because national output is in domestic currency terms. Converting nominal output into a common currency using spot nominal exchange rates greatly exaggerates fluctuations in output because nominal exchange rates are much more volatile than either real production or price levels. Moreover, prices vary considerably across nations even after conversion to a common currency making it difficult to construct an appropriate deflator to convert nominal gross international product into real gross international product. Here we follow much of the existing literature and use real Gross Domestic Product of each country and compute correlations across them. If real output is highly correlated across countries, we have evidence of a world business cycle. As we documented earlier, most macroeconomic aggregates are positively correlated across countries, indicative of a world business cycle. How do business cycle researchers account for this fact?

There are two channels through which positive economic comovement may arise, endogenous propagation and exogenous propagation. Positive endogenous propagation refers to a situation in which a disturbance originating in one country has a positive impact on both home and foreign output levels. For example, rapid development in China drives up demand for crude petroleum and fuels economic expansions in countries that are specialized in oil production. Positive exogenous propagation refers to the correlation of shocks across countries. For example, World War II witnessed dramatic increases in national output in most industrialized countries as government spending rapidly expanded during the conflict. In practice, endogenous and exogenous propagation are difficult to isolate, presenting one of the key challenges of business cycle research.

\footnotetext{
${ }^{10}$ Kollman (1998) appears to be the first quantitative simulation of U.S. and European current account dynamics using a modern real business cycle analysis that incorporates variation in productivity, government spending and national tax rates.
} 
Real business cycle researchers have devoted most of their effort to measuring total factor productivity which has been found to be highly persistent and positively correlated across countries. Correlations over the business cycle are typically lower than correlations over long periods of measurement, suggesting more commonality in the technological trend and in the productivity cycle. ${ }^{11}$ Given the lower correlation of fiscal variables with the cycle and their modest cyclical variation, it is not surprising that they have received less attention in empirical and theoretical analysis than productivity. ${ }^{12}$

Apart from the obvious role of the correlation of the shocks that drive business cycles, three economic factors have proven critical in determining the ability of dynamic equilibrium models to generate international comovements resembling those we see in the data. The first is the extent to which domestic and foreign goods are substitutes in demand. The second is the extent to which factors of production are internationally mobile. The third is the extent of international financial linkages.

The first generation of models by Backus, Kehoe and Kydland (1992) and Baxter and Crucini (1993) followed the analytical structure of the closed economy models by Kydland and Prescott (1982) and King, Plosser and Rebelo (1987) quite closely. Despite the similarity, however, international economists were immediately confronted with two key modeling issues. The first had to do with factor mobility across countries, which is obviously absent in the closed economy setting. The mobility of labor across countries seemed minor enough to ignore, physical capital mobility was not. Since physical capital takes real resources to reallocate, the standard approach has been to subject capital accumulation to adjustment costs (or time to build as in Backus et al (1992)). Without some cost of physical capital mobility, capital would be predicted to move rapidly and in large amounts across national boundaries in response to persistent changes in productivity or taxes. Such factor movements generate strongly negative correlations of output from the supply-side and unrealistically volatile investment over the business cycle.

The second issue model builders were confronted with was asset market struc-

\footnotetext{
${ }^{11}$ When analysis extends to small developing countries the business cycle correlations sometimes exceed the growth correlations.

${ }^{12}$ Two key studies of the empirical behavior of international taxes and their equilibrium implications using dynamic equilibrium theory are Mendoza, Razin and Tesar (1994) and Mendoza and Tesar (1998), respectively. Both studies suggest international taxation is more relevant for secular and long-run trends, than business cycle fluctuations.
} 
ture. Much of aggregative economics is predicated on the basis that idiosyncratic shocks are irrelevant for macroeconomic fluctuations. When thinking about millions of individual agents and thousands of firms, the law of large numbers combined with not-too-objectionable restrictions of preferences and technology provided a compelling argument to abstract from idiosyncratic variation. At the aggregative international level, the number of shocks is small (in many models it is equals the number of countries) and countries are large and few in number. Thus, it makes little sense to rely on the law of large numbers, so researchers adopted the assumption that agents pool nation-specific risks avoiding the need to track the wealth distribution across countries.

Unfortunately, complete risk pooling in the one-sector model leads to a presumption that output is negatively correlated across countries while consumption is close to perfectly positively correlated. In the data, the reverse rankings of correlation tend to prevail and the absolute level of consumption correlations are well below unity. The prediction of near perfect consumption comovement across countries derives from the risk-pooling assumption and the fact that agents face the common prices and interest rates.

The negative correlation of income is driven by cost-minimizing production decisions where firms allocate plants and equipment in the most productive location. Thus an increase in home productivity increases domestic output relative to foreign output directly and this is reinforced by the flow of capital from the less productive country to the more productive country. Risk pooling also enhances the supply-side response by neutralizing the wealth re-distribution effects on home and foreign labor supplies.

Debate continues as to what the appropriate asset market structure should be and how to incorporate changes in asset diversification in business cycle models. Baxter and Crucini (1995) and Kehoe and Perri (2002) show that when risk pooling is limited, positive output comovements are more likely to arise the more persistent are the deviations to relative international productivity. Also, consumption correlations may actually fall below output correlations if the shocks are close to permanent, a feature that is prevalent in the data and difficult to explain from a number of standard theoretical paradigms.

Researchers have had more success accounting for positive international output comovement in models where countries depend on their trading partner's for final goods or intermediate inputs they themselves do not produce. Examples of work along these lines include an extension of the multisector model with intermediate inputs of Long and Plosser (1982) to the open economy by Ambler, Cardia 
and Zimmerman (2002), a model of the North-South business cycle by Michael Kouparitsas (1996) which emphasizes trade of manufactures for primary inputs across these two regions and the introduction of home production by Canova and Ubide (1998). A contribution that extends the incomplete markets model developed by Baxter and Crucini (1995) to the two-good setting is Arvanitis and Mikkola (1996).

\subsection{Real exchange rates and the terms of trade}

Multiple sectors take center stage when considering the real exchange rate and the terms of trade. Approaches to international relative price determination may be usefully placed into two categories. One category focuses on the determination of international relative prices of different goods. A second category focuses on deviations from the Law-of-One-Price, meaning identical goods trade at different prices in different countries.

A classic contribution in the former category is Backus, Kehoe and Kydland (1994), who develop a two country, two good model. Each country specializes in the production of one of the two goods and the two goods are combined in production, via an Armington aggregator, to create a composite final good which is, in effect, the single final good in each economy.

The Armington aggregator is a function that describes how substitutable the two goods are in achieving a particular output level of the final good. To match low trade shares with the specialization in production assumption, home bias is assumed in the aggregator function. This means that the home country uses more of the home good when producing the composite good and the foreign country behaves symmetrically.

This is an elegant model that ties in nicely with the one-sector two-country framework. The key difference between this model and the one-sector model is that specialization provides a motivation for keeping production levels more equal across locations since individuals have demands for each type of good. The model allows us to study the terms of trade, a key international relative price absent from the one-sector model, by construction. In the BKK model, the terms of trade and trade ratio are related as follows:

$$
q_{t}=\ln \left(\frac{p_{b t}}{p_{a t}}\right)=\omega+\frac{1}{\sigma} \ln \left(a_{t} / b_{t}\right)
$$

In words: an increase in production of the home good, $a$, drives down it's relative price. The home terms of trade turn against the country experiencing 
the expansion, a procyclical terms of trade, as BKK define it. In the data, the correlation varies substantially across countries in magnitude and sign. The model has difficulty matching both the observed volatility of the terms of trade and quantity ratio; as the Euler equation makes clear, there is a trade-off between terms of trade and quantity ratio variability as the elasticity is altered. If we view $a$ and $b$ as the final consumption levels of each good, the quantity ratio is not nearly volatile enough, given a plausible elasticity, to generate terms of trade variation we see in the data. Backus and Crucini (2000) add an oil producing region (and sector) and find that the model does better in matching the cyclicality of the terms of trade and the trade balance than the original BKK model. Kose (2002) provides an extensive quantitative analysis of the variation of international relative prices and their role in the business cycles of small open economies.

Models that consider deviations from the Law-of-One-Price differ in the source of the price deviations and their duration. Sticky-price models consider the deviations to be transitory, with nominal prices responding with a lag to changes in the economic environment. These model also assume trade in an infinite number of varieties which allows individual firms to charge a markup of price over marginal cost. Key contributions in this area are Svennson and van Wijgenbergen (1989) and Obstfeld and Rogoff (1995).

Trade cost models treat price deviations as a consequence of a real resource cost of trading, or operating businesses, in different locations. The simplest version allows prices to vary across locations by a shipping cost, usually treated as proportional to the marginal cost of the producer/supplier. The seminal contribution is Samuelson (1952) with more recent contributions by Eaton and Kortum (2002) and Sercu, Uppal and van Hulle (1995). An alternative variant is to distinguish traded and non-traded goods with traded goods not subject to trade costs and non-traded goods assumed to be subject to prohibitive trade costs as in the original Salter (1959) and Swan (1960) models. Stockman and Tesar (1995) conduct a quantitative investigation of the business cycle predictions of this class of model.

Recent efforts have focused on quantifying the role of sticky prices, imperfect competition and trade costs in accounting for international relative price deviations and their business cycle implications. Chari, Kehoe and McGrattan (2002) conduct a quantitative evaluation of the sticky-price, imperfect competition model and find that it can account for only a small part of the persistence and somewhat more of the volatility of the real exchange rate. ${ }^{13}$ Corsetti, Dedola, Leduc

\footnotetext{
${ }^{13}$ See also Betts and Devereux ( 2000), Bergin and Feenstra (2000).
} 
(2005) and Ravn and Mazzenga (2004) show the promise of models that combine imperfect competition with real trading costs.

What is missing from existing models is a clear distinction between economic activities that take place at the dock and exchange in retail markets. Transportation costs alone cannot account for all of the retail price dispersion we observe. Presumably, this is because much of what the retail market entails are local inputs of land, labor and infrastructure (some of it publicly provided). Models and empirical evidence is just now being developed to make these distinctions, such as Burstein, Neves and Rebelo (1993) and Crucini, Telmer and Zachariadis (2005), respectively. 


\section{References}

[1] Ambler, Stephen, Emanuel Cardia and Christian Zimmerman. 2002. International transmission of the business cycle in a multi-sector model. European Economic Review 46, 273-300.

[2] Ambler, Stephen, Emanuela Cardia and Christian Zimmermann. 2004. International business cycles: What are the facts?. Journal of Monetary Economics 51(2), 257-276.

[3] Arvanitis, Athanasios V. and Anne Mikkola. 1996. Asset-Market structure and international trade dynamics, The American Economic Review 86(2), $67-70$.

[4] Backus, David K., and Mario J. Crucini. 2000. Oil Prices and the terms of trade. Journal of International Economics 50(1), 185-213.

[5] Backus, David K., Patrick Kehoe and Finn Kydland. 1992. International real business cycles. Journal of Political Economy 100(4), 745-775.

[6] Backus, David K., Patrick Kehoe and Finn Kydland. 1994. Dynamics of the trade balance and the terms of trade: the J-curve. American Economic Review 84, 84-103.

[7] Baxter, Marianne and Mario J. Crucini. 1993. Explaining saving-investment correlations. American Economic Review 83(3), 416-36.

[8] Baxter, Marianne and Mario J. Crucini. 1995. Business cycles and the asset structure of foreign trade. International Economic Review 36(4), 821-54.

[9] Baxter, Marianne and Dorsey Farr. 2005. Variable capital utilization and international business cycles. Journal of International Economics 65(2), 335347.

[10] Baxter, Marianne and Robert G. King. 1999. Measuring business cycles: approximate band-pass filters for economic time series. Review of Economics and Statistics 81(4), 575-93.

[11] Bergin, Paul R. and Robert C. Feenstra. 2000. Staggered price setting, translog preferences, and endogenous persistence. Journal of Monetary Economics $45(3)$, 657-680. 
[12] Betts, Caroline and Michael Devereux. 2000. Exchange rate dynamics in a model of pricing to market. Journal of International Economics 50, 215-44.

[13] Beveridge, S. and Charles Nelson. 1981. A new approach to decomposition of economic time series into permanent and transitory components with particular attention to measurement of the business cycle. Journal of Monetary Economics 7(2).

[14] Burns, Arthur and Wesley Mitchell. 1946. Measuring Business Cycles. New York: National Bureau of Economic Research.

[15] Burstein, Ariel T., Joao C. Neves and Sergio Rebelo. 2003. Distribution costs and real exchange rate dynamics during exchange-rate based stabilizations. Journal of Monetary Economics 50, 1189-1214.

[16] Canova, Fabio and Ubide, Angel J. 1998. International business cycles, financial markets and household production," Journal of Economic Dynamics and Control, 22(4), 545-572.

[17] Chari, V. V., Patrick J. Kehoe and Ellen R. McGrattan. 2002. Can sticky price models generate volatile and persistent real exchange rates?" Review of Economic Studies 69(3), 533-563.

[18] Cochrane, John H. 1994. Permanent and Transitory Components of GNP and stock prices. The Quarterly Journal of Economics 109(1), 241-265.

[19] Corsetti, Giancarlo, Luca Dedola and Sylvain Leduc. 2005. International riskSharing and the transmission of productivity shocks. Federal Reserve Board International Finance Discussion Paper No. 2005-826.

[20] Crucini, Mario J. and Mototsugu Shintani. 2006. International comovement: Is theory ahead of business cycle measurement?, Vanderbilt University mimeo.

[21] Crucini, Mario J., Chris I. Telmer and Marios Zachariadis. 2005. Understanding European real exchange rates. American Economic Review 95(3), 724-738.

[22] Eaton, Jonathan and Samuel Kortum. 2002. Technology, geography, and trade. Econometrica 70, 1741-1779. 
[23] Engel, Charles and John Rogers. 1996. How wide is the border? The American Economic Review 86(5), 1112-1125.

[24] Feeney, JoAnne. 1994. Goods and asset market interdependence in a risky world. International Economic Review 35(3), 551-563.

[25] Friedman, Milton. 1957. A Theory of the Consumption Function. Princeton, New Jersey: Princeton University Press.

[26] Glick, Reuven and Kenneth Rogoff. 1995. Global versus country-specific productivity shocks and the current account. Journal of Monetary Economics 35(1), 159-192.

[27] Hodrick, Robert and Edward C. Prescott. 1997. Post-War U.S. business cycles: an empirical investigation. Journal of Money, Credit and Banking 28(4), $1-16$.

[28] Imbs, Jean. 1994. Technology, growth and the business cycle. Journal of Monetary Economics 44(1), 65-80.

[29] Kehoe, Patrick J., and Fabrizio Perri. 2002. International business cycles with endogenous incomplete markets. Econometrica 70(3), 907-928.

[30] King, Robert G, Charles I. Plosser and Sergio Rebelo. 1988. Production, growth, and business cycles I: the basic neoclassical model. Journal of Monetary Economics 21, 195-232.

[31] Kollman, Robert. 1998. U.S. trade balance dynamics: the role of fiscal policy and productivity shocks and of financial market linkages, Journal of International Money and Finance 17, 637-669.

[32] Kose, Ayhan. 2002. Explaining business cycles in small open economies: How much do world prices matter? Journal of International Economics 56(2), pages 299-327.

[33] Kose, Ayhan, Christopher Otrok and Charles Whiteman. 2003. International business cycles: world, region, and country-specific factors. The American Economic Review 93(4), 1216-

[34] Kouparitsas, Michael. 1996. North-South business cycles. Federal Reserve Bank of Chicago Working Paper Series No. 96-9. 
[35] Kydland, Finn E. and Edward C. Prescott. 1982. Time to build and aggregate fluctuations. Econometrica 50, 1345-1370.

[36] Long, John and Charles I. Plosser. 1983. Real business cycles. Journal of Political Economic 91 (1983), 39-69.

[37] Mendoza, Enrique. 1991. Real business cycles in a small open economy. American Economic Review 81(4), 797-818.

[38] Mendoza, Enrique, Assaf Razin and Linda L. Tesar. 1994. Effective tax rates in macroeconomics: cross-country estimates of tax rates on factor incomes and consumption. Journal of Monetary Economics 34(3), 297-323.

[39] Mendoza, Enrique and Linda Tesar. 1998. The international ramifications of tax reforms: supply-side economics in a global economy. American Economic Review 88(1), 226-245.

[40] Nason, James and John Rogers. 2006. The present-value model of the current account has been rejected: round up the usual suspects. Journal of International Economics 68(1), 159-187.

[41] Obstfeld, Maurice and Kenneth Rogoff. 1995. Exchange rate dynamics redux. Journal of Political Economy 102, 624-660.

[42] Quah, Danny. 1990. Permanent and transitory movements in labor income: an explanation for excess smoothness" in Consumption. Journal of Political Economy 98(3), 449-475.

[43] Ravn, Morten and Elisabetta Mazzenga. 2004. International business cycles: the quantitative role of transportation costs. Journal of International Money and Finance 23(4), 645-671.

[44] Samuelson, Paul A. 1952. Spatial price equilibrium and linear programming. American Economic Review 42(3), 283-303.

[45] Sachs, Jeffrey D. 1981. The current account and macroeconomic adjustment in the 1970's. Brookings Papers on Economic Activity 1, 201-268.

[46] Salter, W.E. 1959. Internal and external balance: the role of price and expenditure effects. Economic Record 35, 226-38. 
[47] Sercu, Piet, Raman Uppal, and Cynthia Van Hulle. 1995. The exchange rate in the presence of transaction costs: implications for tests of purchasing power parity. Journal of Finance 50(4), 1309-1319.

[48] Stock, James and Mark Watson. 2005. Understanding changes in international business cycle dynamics. Journal of the European Economic Association 3(5), 968-1006.

[49] Svennson, Lars and van Wijgenbergen. 1989. Excess capacity, monopolistic competition and international transmission of monetary disturbances. Economic Journal 99, 785-805.

[50] Stockman, Alan and Linda Tesar. 1995. Tastes and technology in a twocountry model of the business cycle: explaining international comovements. 85(1), 168-85.

[51] Swan, T. 1960. Economic control in a dependent economy. Economic Record 36, 51-66. 
Table 1. - Business cyclical properties of eight industrial countries

\begin{tabular}{|c|c|c|c|c|c|c|c|c|}
\hline & 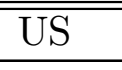 & Australia & Canada & France & Germany & Italy & Japan & $\overline{\mathrm{UK}}$ \\
\hline Std. dev. of output & 1.58 & 1.32 & 1.46 & 0.91 & 1.36 & 1.43 & 1.35 & 1.48 \\
\hline \multicolumn{9}{|c|}{ Panel A. Standard deviations relative to output } \\
\hline Consumption & 0.80 & 0.77 & 0.79 & 0.97 & 0.87 & 0.93 & 0.92 & 1.14 \\
\hline Investment & 2.85 & 3.41 & 2.83 & 3.11 & 2.59 & 2.29 & 2.36 & 2.49 \\
\hline Government & 0.54 & 1.26 & 0.78 & 0.78 & 0.86 & 0.55 & 0.92 & 0.72 \\
\hline Exports & 2.68 & 3.00 & 2.66 & 3.11 & 3.00 & 2.71 & 3.21 & 1.97 \\
\hline Imports & 3.26 & 4.83 & 3.16 & 3.95 & 2.32 & 3.24 & 4.31 & 2.54 \\
\hline Savings & 4.46 & 4.88 & 3.72 & 4.07 & 3.70 & 3.03 & 2.52 & 4.17 \\
\hline Productivity & 0.56 & 0.76 & 0.64 & 1.04 & 0.72 & 0.94 & 0.68 & 0.80 \\
\hline Capital & 0.39 & 0.43 & 0.42 & 2.87 & 1.11 & 1.16 & 0.55 & 0.35 \\
\hline Labor & 0.83 & 1.01 & 0.94 & 0.65 & 0.66 & 0.65 & 0.62 & 1.19 \\
\hline
\end{tabular}

Panel B. Correlation with own-country output

$\begin{array}{lrrrrrrrr}\text { Consumption } & 0.85 & 0.42 & 0.82 & 0.71 & 0.67 & 0.75 & 0.79 & 0.79 \\ \text { Investment } & 0.95 & 0.78 & 0.60 & 0.83 & 0.81 & 0.79 & 0.93 & 0.66 \\ \text { Government } & -0.18 & 0.07 & -0.15 & -0.20 & 0.10 & -0.03 & 0.04 & -0.19 \\ \text { Exports } & 0.42 & 0.11 & 0.67 & 0.72 & 0.62 & 0.24 & 0.05 & 0.48 \\ \text { Imports } & 0.81 & 0.45 & 0.73 & 0.80 & 0.74 & 0.70 & 0.62 & 0.68 \\ \text { Savings } & 0.88 & 0.86 & 0.89 & 0.81 & 0.82 & 0.82 & 0.84 & 0.74 \\ \text { Productivity } & 0.84 & 0.67 & 0.77 & 0.45 & 0.76 & 0.87 & 0.91 & 0.58 \\ \text { Capital } & 0.26 & 0.20 & -0.14 & 0.25 & 0.26 & -0.08 & 0.37 & 0.09 \\ \text { Labor } & 0.90 & 0.68 & 0.84 & 0.67 & 0.81 & 0.47 & 0.75 & 0.67 \\ \text { Net export ratio } & -0.44 & -0.32 & -0.09 & -0.28 & 0.08 & -0.38 & -0.41 & -0.30 \\ & & & & & & & & \\ \text { Correlation of savings } & 0.63 & 0.44 & 0.67 & 0.58 & 0.44 & 0.80 & 0.47 & 0.83 \\ \text { and investment } & & & & & & & & \end{array}$

Notes: All variables expect the net export ratio are the Hodrick-Prescott cycle components. All nominal variables are deflated by the Gross Domestic Product Deflator. The sample period is the first quarter of 1970:1 to the first quarter of 2005 . 
Table 2. - International Business Cycle Comovement Correlation with U.S. counterpart.

\begin{tabular}{|c|c|c|c|c|c|c|c|}
\hline & Australia & Canada & France & Germany & Italy & Japan & UK \\
\hline Output & 0.46 & 0.71 & 0.36 & 0.42 & 0.32 & 0.43 & 0.64 \\
\hline \multicolumn{8}{|c|}{ Panel A. Demand-side } \\
\hline Consumption & -0.09 & 0.53 & 0.37 & 0.37 & 0.01 & 0.35 & 0.50 \\
\hline Investment & 0.29 & 0.16 & 0.25 & 0.47 & 0.15 & 0.42 & 0.40 \\
\hline Government & 0.22 & 0.29 & -0.04 & 0.05 & -0.01 & 0.07 & 0.06 \\
\hline Exports & 0.03 & 0.33 & 0.40 & 0.34 & 0.10 & 0.25 & 0.32 \\
\hline Imports & 0.13 & 0.45 & 0.36 & 0.32 & 0.40 & 0.29 & 0.50 \\
\hline Savings & 0.53 & 0.68 & 0.38 & 0.39 & 0.33 & 0.51 & 0.37 \\
\hline Net exports & -0.18 & -0.50 & -0.08 & 0.23 & -0.29 & -0.16 & 0.07 \\
\hline \multicolumn{8}{|c|}{ Panel B. Supply-side } \\
\hline Productivity & 0.42 & 0.53 & -0.07 & 0.21 & 0.04 & 0.27 & 0.36 \\
\hline Capital & 0.33 & 0.18 & 0.08 & 0.17 & 0.09 & 0.31 & 0.55 \\
\hline Labor & 0.42 & 0.59 & 0.36 & 0.39 & -0.17 & 0.42 & 0.60 \\
\hline
\end{tabular}


Table 3. - Cyclical properties of real exchange rates and the terms of trade

\begin{tabular}{|c|c|c|c|c|c|c|c|c|}
\hline & U.S. & Australia & 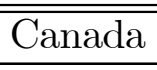 & France & Germany & Italy & $\begin{array}{l}\text { Japan } \\
\end{array}$ & U.K. \\
\hline \multicolumn{9}{|c|}{ Panel A. Standard Deviations } \\
\hline Price ratio & & & & 1.17 & 1.42 & 1.67 & & 1.74 \\
\hline Nominal exchange rate & & & & 8.52 & 8.37 & 8.51 & & 8.20 \\
\hline Real exchange rate & & & & 7.95 & 8.06 & 7.80 & & \\
\hline Terms of trade & 2.90 & 5.21 & 2.44 & 3.50 & 2.61 & & 5.68 & 2.64 \\
\hline Trade ratio & & 9.94 & 4.60 & 3.66 & 3.90 & & 7.29 & 3.94 \\
\hline \multicolumn{9}{|c|}{ Panel B. Contemporaneous Cross-correlations } \\
\hline Output and net exports & -0.30 & -0.19 & -0.43 & -0.30 & -0.05 & & -0.23 & -0.25 \\
\hline Output and the terms of trade & -0.08 & -0.30 & -0.11 & -0.14 & -0.09 & & -0.09 & 0.22 \\
\hline Terms of trade and net exports & 0.28 & -0.07 & 0.06 & -0.51 & 0.00 & & -0.50 & -0.54 \\
\hline
\end{tabular}

Note: The terms of trade and real exchange rate moments are taken from Backus and Crucini (2000) and Chari, Kehoe and McGrattan (2002), respectively. 
Figure 1. Business cycles in eight industrialized countries
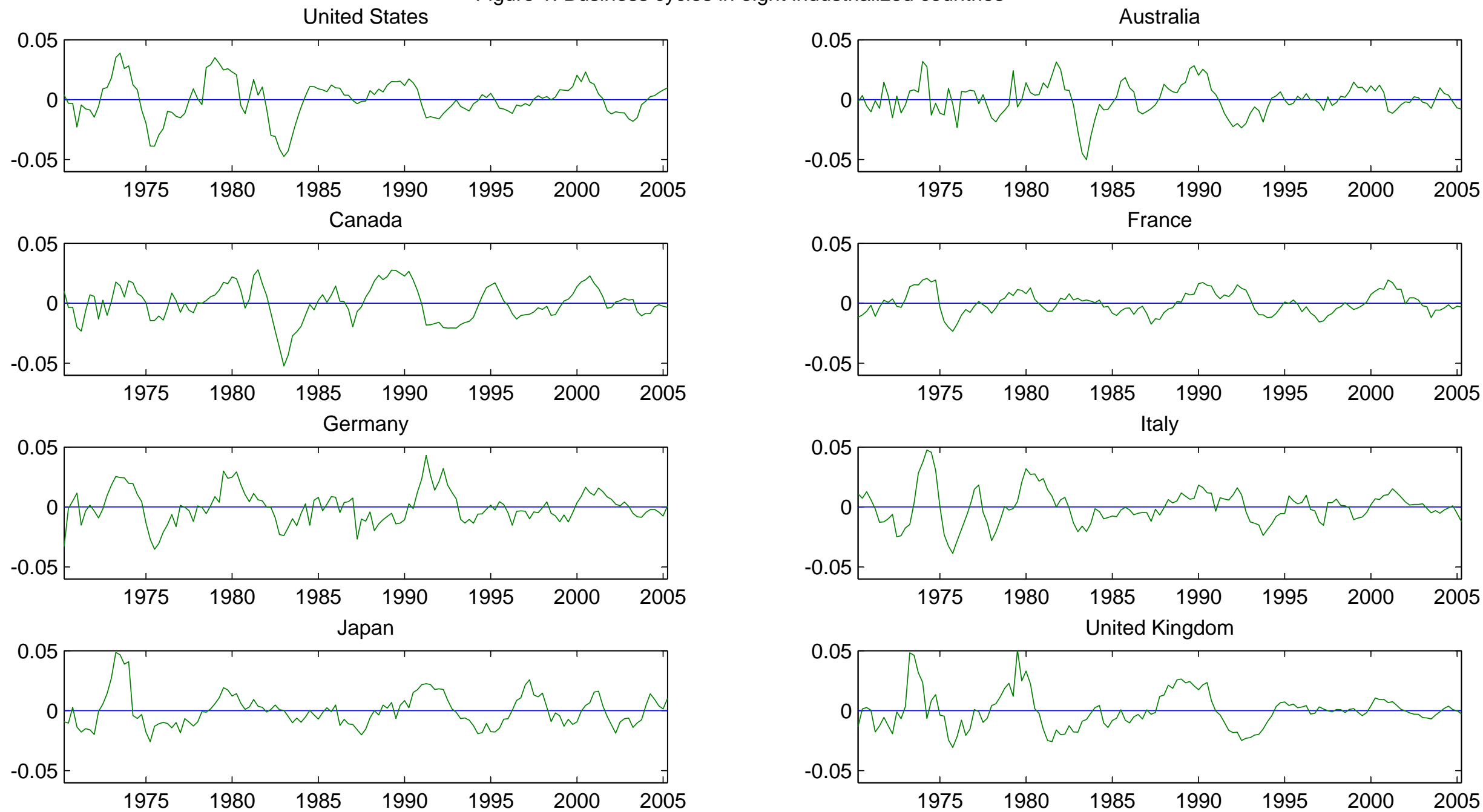